\title{
Author Correction: Large subglacial source of mercury from the southwestern margin of the Greenland Ice Sheet
}

Jon R. Hawkings (D), Benjamin S. Linhoff, Jemma L. Wadham, Marek Stibal (D), Carl H. Lamborg, Gregory T. Carling (iD, Guillaume Lamarche-Gagnon (D), Tyler J. Kohler, Rachael Ward, Katharine R. Hendry (D), Lukáš Falteisek, Anne M. Kellerman, Karen A. Cameron (D), Jade E. Hatton, Sarah Tingey, Amy D. Holt, Petra Vinšová (D), Stefan Hofer (iD, Marie Bulínová, Tomáš Větrovský, Lorenz Meire iD and Robert G. M. Spencer

Correction to: Nature Geoscience https://doi.org/10.1038/s41561-021-00753-w, published online 24 May 2021.

In the version of this Article originally published online, the affiliation "US Geological Survey, Albuquerque, NM, USA" was mistakenly not listed as a present address; this has now been corrected and the other affiliations renumbered accordingly. All versions of the Article have been amended.

Open Access This article is licensed under a Creative Commons Attribution 4.0 International License, which permits use, sharing, adaptation, distribution and
reproduction in any medium or format, as long as you give appropriate credit to the original author(s) and the source, provide a link to the Creative Commons
license, and indicate if changes were made. The images or other third party material in this article are included in the article's Creative Commons license, unless
indicated otherwise in a credit line to the material. If material is not included in the article's Creative Commons license and your intended use is not permitted by statutory
regulation or exceeds the permitted use, you will need to obtain permission directly from the copyright holder. To view a copy of this license, visit http://creativecommons.org/
licenses/by/4.0\%.

Published online: 30 June 2021

https://doi.org/10.1038/s41561-021-00804-2

(C) The Author(s) 2021

\section{Publisher Correction: Megathrusts exhumed}

Correction to: Nature Geoscience https://doi.org/10.1038/s41561-021-00757-6, published online 7 May 2021.

In the version of this Editorial originally published, in the sentence beginning "An Article by Mallick et al." the year of the earthquake was mistakenly given as '1868' instead of '1861'; it has now been corrected in the online versions of the Editorial.

Published online: 4 June 2021

https://doi.org/10.1038/s41561-021-00782-5

๑) Springer Nature Limited 2021 